\title{
FLORIDA STATE UNIVERSITY RADIOCARBON DATES I
}

\author{
J. J. STIPP*, G. A. KNAUER, and H. G. GOODELL
}

Radiocarbon Dating Laboratory, Department of Geology

The Florida State University, Tallahassee, Florida

Laboratory construction was begun in December 1964 and routine dating was in progress by late February 1965. The primary purpose of this facility is to assist in marine geological studies and the archaeological chronologies of the region. Dating is carried out by utilizing the techniques of liquid scintillation described by Noakes et al. (1965), wherein the carbon of the sample to be dated is converted to benzene and the natural radioactivity detected in a liquid scintillation spectrometer.

After sample pretreatment to remove non-contemporaneous carbon, the sample is chemically converted as follows:

$$
\text { Sample } \rightarrow \mathrm{CO}_{2} \rightarrow \mathrm{C}_{2} \mathrm{H}_{2} \rightarrow \mathrm{C}_{6} \mathrm{H}_{6}
$$

Conversion to $\mathrm{CO}_{2}$ is a fairly standard procedure in all laboratories and therefore will not be discussed. Conversion of $\mathrm{CO}_{2} \rightarrow \mathrm{C}_{2} \mathrm{H}_{2}$ via $\mathrm{Li}_{2} \mathrm{C}_{2}$ is an adaption of the technique used by Barker (1953), which gives consistent chemical yields of $95-98 \%$. Conversion of acetylene to benzene is carried out through the action of a vanadium-alumina catalyst which gives yields of $85-92 \%$ of very pure benzene.

Noakes, Kim and Stipp (1965) undertook mass spectrometric studies at the Oak Ridge National Laboratories on the possible isotopic fractionation in the conversion of acetylene to benzene prepared both by the original diborane-activated silica-alumina catalyst described by Noakes et al. (1963) and with the new high-valence metal oxide catalysts described by Noakes, Kim and Akers (1965). In this study he found that even over a large range of induced experimental yields $(30-98 \%)$ there was no isotopic fractionation. This had previously been indicated through reproducibility studies (Stipp et al., 1962; Noakes et al., 1964; Tamers et al., 1964; McDowell and Ryan, 1965), and through statistical comparison techniques (Tamers and Pearson, 1965).

Barker's (pers. comm., 1962) acetylene purification method, using columns filled with glass beads coated with concentrated phosphoric acid and $50 \% \mathrm{KOH}$, has insured against quenching by removing nitrogenhydrogen and sulphur products.

Radon, if initially present, should be removed during the high temperature evacuation carried out on the hot lithium carbide. Apparently this step is quite effective as no radon has ever been seen to contaminate any of the counting solutions.

* Present address: Department of Geophysics and Geochemistry, Australian National University, Canberra, A.C.T. Australia. 
Detection is carried out in an ANS, Inc. automatic two-channel Liquid Scintillation Spectrometer. It has been shown previously by McDowell (pers. commun., 1964) and Pietig and Scharpenseel (1964) that supplemental shielding with mercury in liquid counting has a significant effect in reducing background levels. Therefore, in cooperation with ANS, Inc., an experiment at Florida State University using a two-in. shield of triple-distilled mercury in place of the standard lead shield was carried out with the result that backgrounds were lowered by approx. $20 \%$. The standard vial size chosen is $5 \mathrm{cc}$ which gives a background of 7.41 counts $/ \mathrm{min}$ and a modern standard rate (age-corrected 1860 wood) of 34.87 counts/min yielding an age range of $44,000 \mathrm{yr}$ for a two-sigma deviation and 48 hour counting period. For older samples a $15 \mathrm{cc}$ vial is used with a background rate of 12.82 counts/min and a modern rate of 111.16 counts $/ \mathrm{min}$, with an extension of age range to $51,800 \mathrm{yr}$ on the same criterion.

The possibility of sample quenching is closely monitored both by the channels ratio and the automatic external standardization method employing a $\mathrm{Cs}^{137}$ gamma source $\left(5_{\mu \mathrm{c}}\right)$. Both methods are sensitive in detecting any sample or electronic discrepancies to less than one percent.

The modern standard, once accurately determined, is checked daily thereafter with a "hot" reference standard (Pearson, pers. commun., 1964; Noakes et al. 1965). This technique has allowed nearly continuous monitoring of the modern rate while at the same time eliminating the necessity for frequent and time-consuming preparation of modern samples.

Data calculation is done by a Fortran II program which also analyzes continuous instrument performance from the frequent-interval data print-out. Arrangements are now being made to print the raw data onto a coded punch tape to further facilitate handling.

Dates contained in the following partial list were calculated using the Libby half-life of $5570 \mathrm{yr}$ and reported with their counting error uncertainty of 1 standard deviation. Because of the lack of suitable massspectrometric facilities no corrections are made for natural $\mathrm{C}^{13} / \mathrm{C}^{12}$ ratio fluctuations. All collectors and submitters of samples from Florida State University, Tallahassee, Florida, unless stated otherwise.

\section{ACKNOWLEDGMENTS}

Chemical equipment was purchased with NSF grant G 19615. We wish to thank the personnel of the FSU computing center for their help in programming and also Dr. George W. DeVore for his continuous support of the project.

Dr. G. Ostlund of the University of Miami Radiocarbon Dating Laboratory and Mr. J. Pearson of the University of Texas Radiocarbon Dating Laboratory kindly provided us with several check samples.

We are particularly grateful to Mr. Dennis Cassidy for his invaluable technical assistance during the laboratory's construction. 


\section{SAMPLE DESGRIPTIONS}

I. CHECK SAMPLES

\begin{tabular}{|c|c|c|c|c|}
\hline $\begin{array}{l}\text { Florida } \\
\text { number }\end{array}$ & Florida date & $\begin{array}{l}\text { Other } \\
\text { number }\end{array}$ & $\begin{array}{c}\text { Other } \\
\text { date }\end{array}$ & Reference \\
\hline $\begin{array}{l}\text { FSU-1a } \\
\text { FSU-1b } \\
\text { FSU-1c }\end{array}$ & $\left.\begin{array}{l}2320 \pm 100 \\
2360 \pm 80 \\
2380 \pm 80\end{array}\right\}$ & ML-86 & $2025 \pm 55$ & Miami I-III \\
\hline FSU-2 & $9880 \pm 230$ & ML-153B & $9900 \pm 105$ & Miami I-III \\
\hline FSU-3 & $11,245 \pm 450$ & $\begin{cases}\mathrm{C} & -800 \\
\mathrm{TX} & -44 \\
\mathrm{~L} & -6980\end{cases}$ & $\begin{array}{l}10,856 \pm 410 \\
10,700 \pm 210 \\
11,840 \pm 100\end{array}$ & $\begin{array}{l}\text { Chicago IV } \\
\text { Texas II } \\
\text { Broecker and } \\
\text { Farrand (1963) }\end{array}$ \\
\hline
\end{tabular}

\section{GEOLOGIC SAMPLES}

A. South-East U. S.

\section{Tampa Bay series, Florida}

Oyster shell and meat from various localities within Tampa Bay. Oysters were living at time of collection and were measured to provide indication of any significant difference in natural fractionation between shell and flesh fractions of modern oysters. Results were correlated with $\mathrm{pH}$, salinity and temperature data. Coll. May 1965 by C. H. Solomon, U. S. Dept. of Interior; subm. by H. S. Rydell.

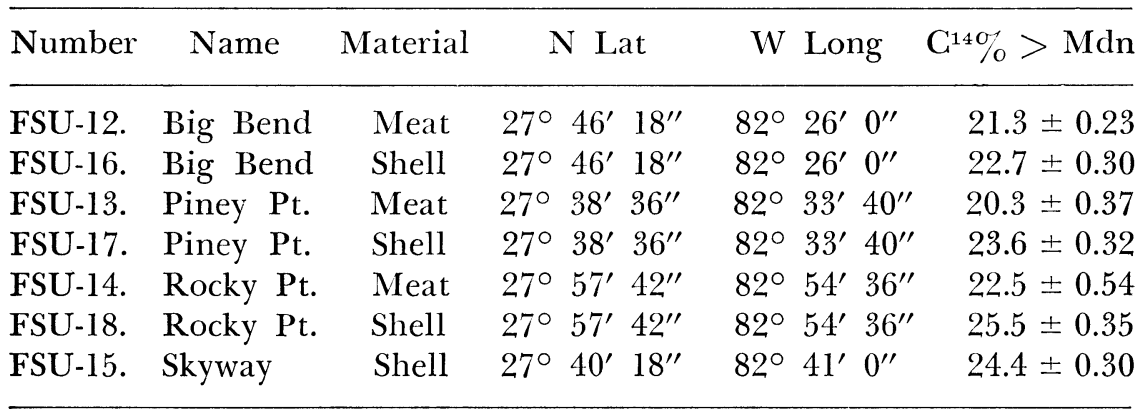

\section{Appalachicola Bay series, Florida}

Samples are of recent and Pleistocene surface and subsurface wood and shell material collected between Cape San Blas and Alligator Harbor, Florida. Dates represent part of study of coastal evolution of Appalachicola delta region of NW Florida with respect to late PleistoceneHolocene sealevel fluctuations. Coll. 1964 and early 1965. Subm. 1965 by J. Schnable. 
FSU-23. St. George-1

A.D. 1390

$560 \pm 100$

Wood from taproot stump of pine tree in growth position and now awash (intertidal) on present beach. Coll. $1 / 2 \mathrm{mi}$ SW of New Pass, St. George Island, Florida (29० $36^{\prime} 30^{\prime \prime} \mathrm{N}$ Lat, $84^{\circ} 58^{\prime} 20^{\prime \prime} \mathrm{W}$ Long).

FSU-24. Royal Bluff

$4610 \pm 625$

Sandy fresh-water peat from intertidal zone coll. W of Carrabelle on mainland shore approx. $1 \mathrm{mi} \mathrm{E}$ of Royal Bluff, Florida $\left(29^{\circ} 48^{\prime} 6^{\prime \prime}\right.$ N Lat, $84^{\circ} 44^{\prime} 18^{\prime \prime}$ W Long).

FSU-25. Alligator Harbor

$1390 \pm 175$

Wood chips from peat layer ca. $1 \mathrm{ft}$ above MSL from $\mathrm{E}$ shore of Alli-

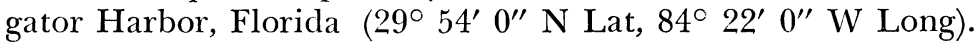

FSU-26. Alligator Harbor

$350 \pm 120$

Wood from taproot stump of pine tree in growth position and now awash (intertidal) on present beach. Coll. from SW Cape on Alligator Spit (29 $53^{\prime} 30^{\prime \prime} \mathrm{N}$ Lat, $84^{\circ} 22^{\prime} 30^{\prime \prime} \mathrm{W}$ Long).

FSU-28. St. George-3

$40,340+1630$

Log, probably driftwood, at $41 \mathrm{ft}$ below MSL in continuously cored section of Pleistocene sediments. Boring site in old dune area on St.

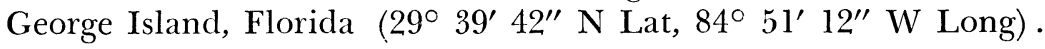

FSU-29. St. George-4

$>30,000$

Wood fragments, probably driftwood, at $36 \mathrm{ft}$ below MSL in continuous cored section of Pleistocene sediments. Boring site on present beach, St. George Island, Florida (29 $39^{\prime} 36^{\prime \prime} \mathrm{N}$ Lat, $84^{\circ} 51^{\prime} 12^{\prime \prime} \mathrm{W}$ Long).

FSU-30. St. George-5

Wood fragments, probably driftwood, at $38 \mathrm{ft}$ below MSL from a boring site in old dune area on St. George Island, Florida $\left(29^{\circ} 39^{\prime} 42^{\prime \prime}\right.$ N Lat, $84^{\circ} 52^{\prime} 24^{\prime \prime}$ W Long).

FSU-31. St. George-6

$$
30,700+2760
$$

28,750 B.c.

Wood fragments, probably driftwood, at $37.5 \mathrm{ft}$ below MSL in a continuously cored section of Pleistocene sediments. Boring site on present beach, St. George Island, Florida (29 $39^{\prime} 36^{\prime \prime} \mathrm{N}$ Lat, $84^{\circ} 51^{\prime} 12^{\prime \prime}$ W Long). 
FSU-32. Lanark Village

$3780 \pm 330$

Wood fragments in a subsurface sandy peat from ca. $5 \mathrm{ft}$ below MSL. Boring site on bayshore, Lanark, Florida $\left(29^{\circ} 52^{\prime} 51^{\prime \prime} \mathrm{N}\right.$ Lat, $84^{\circ}$ $35^{\prime} 48^{\prime \prime}$ W Long).

FSU-33. St. George-7

$4100 \pm 110$

Oyster shells (Crassostrea virginica), from bay deposit $18 \mathrm{ft}$ below MSL. Boring site on bayside of St. George Island ca. $1 \mathrm{mi} \mathrm{W}$ of ferry landing $\left(20^{\circ} 39^{\prime} 48^{\prime \prime} \mathrm{N}\right.$ Lat, $84^{\circ} 52^{\prime} 0^{\prime \prime} \mathrm{W}$ Long).

FSU-34. St. George-8

$4370 \pm 420$

2420 B.c.

Reworked oyster shells (Crassostrea virginica), from barrier island sand deposit $12.5 \mathrm{ft}$ below MSL. Boring site on bay side of St. George Island ca. $1 \mathrm{mi} \mathrm{W}$ of ferry landing (same location as FSU-33). Comment: although FSU-33 and FSU-34 appear to be reversed, they are statistically indistinguishable.

Comment (J.S.): dates in the 30,000 to 40,000 yr B.P. range indicate possibility of a relatively high stand of sea during mid-Wisconsin. Dates are on wood believed to be driftwood occurring in subsurface Pleistocene sediments. Dates less than 5000 yr B.P. on wood fragments and oyster shells give some indication of Holocene sealevel rise. More dates concerning this study will be published in the future.

\section{Alligator-Horeshoe Creek series}

Fossil wood buried at various depths in recent soils from the drainage area of Alligator and Horseshoe Creeks, in Gulf Co., Florida. These samples, plus others to be dated, should indicate rate of soil formation in the respective areas. Coll. 1965 by B. Williamson of Gulfland Timber Co., Florida; subm. 1965 by W. F. Tanner.

FSU-59. Gulf Co.-1

$1520 \pm 80$

From hillside in Gulf Co., Florida $\left(30^{\circ} 6^{\prime} 54^{\prime \prime} \mathrm{N}\right.$ Lat, $85^{\circ} 15^{\prime} 16^{\prime \prime} \mathrm{W}$ Long), at 29 in. depth.

FSU-60. Gulf Co.-2

$$
520 \pm 140
$$

A.D. 1430

From hillside in Gulf Co., Florida (30 $3^{\prime} 34^{\prime \prime} \mathrm{N}$ Lat, $85^{\circ} 15^{\prime} 17^{\prime \prime}$ W Long), at 10 in. depth.

FSU-61. Gulf Co.- $\mathbf{3}$

A.D. 1470

$480 \pm 145$

From hilltop in Gulf Co., Florida (30 $3^{\prime} 22^{\prime \prime} \mathrm{N}$ Lat, $85^{\circ} 15^{\prime} 9^{\prime \prime} \mathrm{W}$ Long), at 11 in. depth.

FSU-62. Gulf Co.-4

From flood plain in Gulf Co., Florida $\left(30^{\circ} 2^{\prime} 5^{\prime \prime} \mathrm{N} \mathrm{Lat,} 85^{\circ} 15^{\prime} 2^{\prime \prime}\right.$ W Long), at 25 in. depth. 
Comment (W.F.T.): FSU-61, only hilltop sample of the four, yielded fastest rate of soil formation ( $1 \mathrm{in} . / 43 \mathrm{yr}$ ). FSU-62, the only floodplain sample, yielded slowest rate ( 1 in./106 yr). The other two (hillside samples) taken ca. $4 \mathrm{mi}$ apart, produced essentially identical rates of soil formation ( $1 \mathrm{in} . / 52 \mathrm{yr}$ ). This was unexpected, as hilltop soils normally develop less rapidly than floodplain material. Several explanations are being considered pending further dates.

\section{Eltanin series}

\section{B. Antarctic}

Core samples of foraminiferal ooze (Globigerina parhyderma) taken during U.S.N.S. Eltanin Cruise 10. These were used to compare $\mathrm{Th}^{230} / \mathrm{Th}^{232}$ age method with $\mathrm{C}^{14}$ method. Coll. Nov. 1964 by I. Zemmels; subm. Mar. 1965 by C. Holmes.

\section{FSU-46. Pacific Basin}

$18,240 \pm 1050$

From E edge of SE Pacific Basin (64 $5^{\prime} 30^{\prime \prime} \mathrm{S}$ Lat, $75^{\circ} 19^{\prime} 42^{\prime \prime} \mathrm{W}$ Long). Sample taken from Core No. $10-15,0$ to $10 \mathrm{~cm}$ from top of core.

\section{FSU-47. Pacific Rise}

$22,460 \pm 925$

From E edge of SE Pacific Rise $\left(64^{\circ} 10^{\prime} 30^{\prime \prime} \mathrm{S}\right.$ Lat, $75^{\circ} 18^{\prime} 0^{\prime \prime} \mathrm{W}$ Long). Sample taken from Core No. 10-14, 5 to $15 \mathrm{~cm}$ from top of core.

\section{FSU-48. Pacific Basin}

$23,940 \pm 925$

From E edge of SE Pacific Basin (64. $5^{\prime} 30^{\prime \prime} \mathrm{S}$ Lat, $75^{\circ} 19^{\prime} 32^{\prime \prime} \mathrm{W}$ Long). Sample taken from Core No. 10-15, 20 to $30 \mathrm{~cm}$ from top of core.

FSU-49. Drake Passage

$>23,600$

From middle of Drake Passage $\left(60^{\circ} 2^{\prime} 0^{\prime \prime} \mathrm{S}\right.$ Lat, $64^{\circ} 54^{\prime} 0^{\prime \prime} \mathrm{W}$ Long). Sample taken from Core No. 4-14, 85 to $95 \mathrm{~cm}$ from top of core. Comment: dates from the two methods (Holmes, 1962) were found to differ by a factor of $2, \mathrm{C}^{14}$ ages being younger.

\section{FSU-57. Pacific Ridge}

$11,960 \pm 265$ 10,010 B.c.

Sample of Globigerina pachyderma, Globigerina bulloides, and Globigerina inflata, off Pacific Antarctic Ridge ( $54^{\circ} 25^{\prime} 0^{\prime \prime}$ S Lat, $129^{\circ}$ $37^{\prime} 36^{\prime \prime}$ W Long), at $1890 \mathrm{fm}$ depth. Taken from trigger core No. 24, 0 to $19 \mathrm{~cm}$ from top of core on U.S.N.S. Eltanin, Cruise 13. Coll. 1964 by M. Boeuf; subm. 1965 by H. Goodell.

FSU-50. Scotia Ridge

$9730 \pm 255$ 7780 B.C.

Unidentified coral dredged from a seamount $\left(59^{\circ} 56^{\prime} 8^{\prime \prime} \mathrm{S}\right.$ Lat, $34^{\circ}$ $41^{\prime} 1^{\prime \prime}$ to $34^{\circ} 32^{\prime} 7^{\prime \prime} \mathrm{W}$ Long), at $620 \mathrm{fm}$ depth. Coll. 1964 by S. Koster; subm. 1965 by H. Goodell. Comment: gives date B.P. that coral lived and 
since no living coral has been found on Sars Bank in this locality at present time it gives a max time for sealevel rise.

III. ARCHAEOLOGIC SAMPLES

\section{FSU-63. Basin Bayon West, Florida}

$1150 \pm 150$

Charcoal from ramp fill of primary mound at Site WL 13, Walton Co., Florida ( $30^{\circ} 29^{\prime} 59^{\prime \prime} \mathrm{N}$ Lat, $86^{\circ} 14^{\prime} 30^{\prime \prime} \mathrm{W}$ Long). Site excavated by Moore (1901) and assigned to Weeden Island I Phase by Willey (1949). Coll. 1958 and subm. 1964 by W. Lazarus, Fort Walton Beach, Florida. Comment: date closely approximates midrange of Weeden Island phase.

\section{FSU-65. Butcherpen Mound, Florida}

$945 \pm 140$

Charcoal lumps in Pit 1, Level 2, of Site Sa29 in association with E

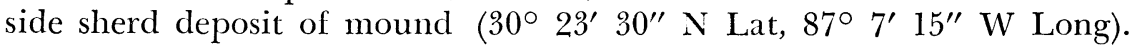
Comment: may date Weeden Island II Phase on this part of Gulf coast. Coll. 1961 and subm. 1964 by W. Lazarus.

\section{FSU-64. Alligator Lake, Florida}

$3085 \pm 130$

1135 B.C.

Charcoal from pit in Area A of Site W1 29, Walton Co., Florida. Site is reported by Lazarus (1965) $\left(30^{\circ} 20^{\prime} 10^{\prime \prime} \mathrm{N}\right.$ Lat, $86^{\circ} 12^{\prime} 10^{\prime \prime} \mathrm{W}$ Long). Coll. and subm. by W. Lazarus. Comment: sample was in association with a vessel of Alexanders type.

\section{FSU-68. Buck Site, Alabama}

$$
210 \pm 85
$$

Charred wood from a feature containing oyster shells and cultural material of Fort Walton Phase at Site 1 Ba 56, Baldwin Co., Alabama (30 $17^{\circ} \mathrm{N}$ Lat, $87^{\circ} 43^{\prime} \mathrm{W}$ Long). Coll. 1965 by D. White; subm. 1965 by D. Phelps. Comment: date seems late for Fort Walton Phase, but duration of phase is little known at present in this area.

\section{Tucker Site series, Florida}

Charred material from surfaces and interiors of vessel fragments obtained from eroding beach component of Tucker Site (Fr 4), Florida $\left(29^{\circ} 55^{\prime} 15^{\prime \prime} \mathrm{N}\right.$ Lat, $84^{\circ} 22^{\prime} 31^{\prime \prime} \mathrm{W}$ Long). Burial mounds on site were excavated by Moore (1902). Willey (1949) records the site, and Sears (1963) did stratigraphic testing in a few undisturbed areas. The beach component was not sampled by previous studies because it was covered by salt marsh. Coll. and subm. 1965 by D. Phelps.

\section{FSU-67. Tucker, Norwood}

Charred fiber from sherd interiors of the types Norwood Plain and Norwood Simple Stamped recently described by Phelps (1965). Comment: date fits into the reported range of fiber-tempered ceramics in SE U.S. (Bullen, 1961). 
FSU-66. Tucker, Gulf Check Stamped

$1605 \pm 325$

Charred organic residue from exterior of vessel of the type Gulf Check Stamped (Willey, 1949). Comment: no absolute dates have been previously reported for this type.

Date lists:

REFERENCES

Chicago IV Libby 1954

Miami I-III Östlund et al., 1965

Texas I Stipp et al., 1962

Texas II Tamers et al., 1964

Texas A\&M I Noakes et al., 1964

Barker, H., 1953, Radiocarbon dating: Large scale preparation of acetylene from organic material: Nature, v. 172, p. 631-632.

Broecker, W. S., and Farrand, W. R., 1963, Radiocarbon age of the Two Creeks Forest Bed, Wisconsin: Geol. Soc. Am. Bull., v. 74, p. 795-802.

Bullen, R. C., 1961, Radiocarbon dates for southeastern fiber-tempered pottery: Am. Antiquity, v. 27, no. 1, p. 104-106.

Holmes, C. W., 1965, Rates of sedimentation in the Drake Passage: Unpub. Ph.D. dissert., Florida State Univ.

Lazarus, W. C., 1965, Alligator Lake, a ceramic horizon site on the northwest Florida Coast: The Florida Anthropologists, v. 18, no. 2, p. 83-124.

McDowell, L. L., and Ryan, M. E., 1965, U. S. Department of Agriculture Sedimentation Laboratory radiocarbon dates I: Radiocarbon, v. 7, p. 174-178.

Moore, C. B., 1902, Certain Aboriginal remains of the northwest Florida Coast, part I: Tour. Acad. Nat. Sci., Philadelphia, v. 12, p. 456-458.

Noakes, J. E., Isbell, A. F., Stipp, J. J., and Hood, D. W., 1963, Benzene synthesis by low temperature catalysis for radiocarbon dating: Geochim. et Cosmochim. Acta, v. 27, p. $797-804$.

Noakes, J. E., Kim, S. M., and Stipp, J. J., 1965, Chemical and counting advances in liquid scintillation age dating: Internat. $\mathrm{C}^{14}$ and $\mathrm{H}^{3}$ Dating Conf., Pullman, Washington, June 7-11, Proc.

Noakes, J. E., Kim, S. M., and Akers, L. K., 1965, Cobalt molybdate catalyst for ambient temperature synthesis of benzene used in radiocarbon dating: Report ORINS-50.

Noakes, J. E., Stipp, J. J., and Hood, D. W., 1964, Texas A\&M University radiocarbon dates I: Radiocarbon, v. 6, p. 189-193.

Östlund, H. G., Bowman, A. L., and Rasnak, G. A., 1965, University of Miami radiocarbon corrections I-III: Radiocarbon, v. 7, p. 153-155.

Phelps, D. S., 1965, The Norwood series of fiber-tempered ceramics: Southeastern Archacol. Conf. Bull., v. 2, p. 65-69.

Pietig, F., and Scharpenseel, H. W., 1964, Age determination with the liquid scintillation spectrometer. Effectiveness of screening measures: Atompraxis, v. 7, p. 306-308.

Sears, W. J., 1963, The Tucker site on Alligator Harbor, Franklin Co., Florida: Contributions of Florida State Mus., Social Sciences, no. 9.

Stipp, J. J., Davis, E. M., Noakes, J. E., and Hoover, T. E., 1962, University of Texas radiocarbon dates I: Radiocarbon, v. 4, p. 43-50.

Tamers, M. A., Pearson, F. J., Jr., and Davis, E. Mott, 1964, University of Texas radiocarbon dates I: Radiocarbon, v. 6, p. 138-159.

Tamers, M. A., and Pearson, J. F., Jr., 1965, Isotope effect in the liquid scintillation method for radiocarbon dating: Nature, v. 205, p. 1205.

Willey, G. R., 1949, Archeology of the Florida Gulf Coast: Smithsonian Inst. Misc. Collections, v. 113. 